\title{
Organizational Resources and Strategy Implementation in Non-Profit Organizations; A Case of Kenya Medical Research Institute, Kenya
}

\author{
Ngui David Lavu, James Rugami Maina
}

Department of Business Administration, Kenyatta University, Kenya

\section{ABSTRACT}

Most NPOs in Kenya have not fully embraced the use of strategic plans due to the difficulties involved in development implementing of strategic plans. There are many factors that hamper implementation of strategic planning an organisation including inadequate financial resources, human resources, technological competences and organisational culture. The aim of the study was to determine the influence of organizational resources on Strategy Implementationin Non-Profit Organizations with a key focus on The Kenya Medical Research Institute Wellcome Trust Research Programme based in Kilifi County, Kenya. The specific objectives of the study were to examine influence of financial resources on strategic plan implementation, influence of human resources, and influence of technological competences on strategic plan implementation. The study was guided two theories, Resource Based View theory and Learning organisation theory. The research employed a descriptive survey research design. The study's population was the management staff at KWTRP who were 60 according to the KWTRP (2018). Since the population was small, a census was adopted. The primary data was collected by use of self-administered semi-structured questionnaire. Data analysis was done by use of descriptive statistics such as frequencies, percentages, mean scores and standard deviation with the aid of SPSS and presented through tables, charts, graphs, frequencies and percentages. The study established that human resources, financial resources and technology competence had a positive and significant influence on the implementation of strategy at KWTRP. The study concluded that an organization's workers important assets as they consistently contribute to an organization's efficient functioning. That proper allocation of financial resources allows managers to put together more productive and efficient workplace teams and enables them to assess their schedules and predict the availability of resources in real time effectively and that technology competence lies in its ability to streamline interaction both internally and externally. One of the essential benefits of software expertise is its potential by promoting strategic thinking and knowledge transfer to improve the competitive advantage of an organization in the marketplace. The study recommends that the organisation incorporate top-down and bottom-up plan development on human resources in order to gain input from the lower management tier and involve workers in formulating strategies in order to significantly increase their contribution to executing a strategy. The study advises that the leadership of the institute should provide enough financial resources to execute strategies effectively. For each assignment within the plan, periodic cost estimates are important so that the use of financial resources can be made as efficiently as possible. On technology competence, the study suggests that management should seek more support for technical ways of executing strategies by having clear and articulated career paths for their staff, leave room for improvement to ensure cohesion of efforts in support of the implementation of the strategy. Similar studies should be carried out in private and public organizations since this study only focussed on nonprofit organizations.

Key Words: Organizational Resources, Human Resources, Financial Resources, Technological Competence, Strategy Implementation, Non-Profit Organizations, Kenya Medical Research Institute 
DOI: $10.35942 /$ ijcab.v3iVI.77

\section{Cite this Article:}

Ngui, D., \& Maina, J. (2019). Organizational Resources and Strategy Implementation in NonProfit Organizations; A Case of Kenya Medical Research Institute, Kenya. International Journal of Current Aspects, 3(VI), 33-51. https://doi.org/10.35942/ijcab.v3iVI.77

\section{Introduction}

Strategic Implementation entails the practices which helps in turning strategies and structures into actions to effectively accomplish specific goals. Executing an organization's strategic plan is as crucial as or even more crucial than the strategy itself. Abuya (2011) alludes that key critical activities help in moving the strategic structure from documents in which its based to actions. According to a Fortune cover story (1999) in a publication on strategic plan implementation, nine of ten firms failed at implementing their framework plan for various reasons; Sixty percent of the firms do not have a plan of action of effectively budgeting for the strategic plan implementation while seventy-five percent of the firms do not link staff incentives to strategic plans, eighty-six percent of senior management spend less than one hour monthly discussing on the firm's strategy while ninety-five percent did not have no knowledge of the organization's strategic plan. The organization's plan offers a business with a defined path it requires in pursuing a strategic direction and set of performance of the organization's objectives. Though, this is basically the plan, it never guarantees that the expected set objective is achieved any more than adopting a path that enables the traveler to arrive at the expected destination.

Pearce and Robinson (2004) hold that strategy implementation is a tendency that remains stable over time and its main goal is to fold the future into the present. Strategic management involves deciding which customer to serve, with which products and services, and meeting those customers' legitimate needs and wants by allocating resources in the most advantageous way (Cole, 2004). Therefore, organizations usually engage in strategic implementation due to the need to support, strengthen and direct the organization's human and other resources in the beneficial achievements of the needs of customers, business owners or shareholders. Most organizations especially nonprofit making, have weak internal, institutional and management mechanisms and above all poor strategic management criteria. The organizations are to a small extent controlled by the state or regulatory agencies. As Strategic implementation is a critical stage in the strategic management process, diligent use of resources among other factors need to be handled properly to ensure proper execution of the strategy as planned. This study sought to establish how organizational resources affect the process the implementation of strategy among Non-profit organisations in Kenya with a key emphasis on the Kenya Medical Research Institute, Kilifi.

Resources in an Organization are aassets that a firm has that can be drawn during the production process. According Barney (1991) organizational resources consist of all benefits, potential, structure, attributes and information owned by an Organization that gives it power to choose and adopt systems that enhances its profitability and long-term goals. As stated by Mahoney and Wang (2009), learning through training and development actions taken by a firm makes human resource to be more specific to the firm and thus may not of much use to the competitor because of their unique nature and thus making it impossible to copy leading to higher market share than the competitors. Baker et al (2009) pointed out that, technology has been noted to be a key factor in initiating novel actions which increases performance of the firm than its competitors. Firms paying attention to technological advancement through research and development produce better than expected performance according to Paladino (2009). Organizations that use technology have been 
considered to have superior performance as they can believe in acquisition of new technologies of product innovation (Altindag Et al, 2010). The recommendation of the study was that firms should give more attention to technological development in order to achieve sustainability. Wernerfelt (2014) did conclude that resource s such as technology and human resources greatly contribute to the effective performance of organization. Besides, the study did establish that there is a positive connection between the firm's resource sand competitive advantages in strengthened by the VRIN factor.

Human resources have a greater correlation with the organization's superior performance has they have a direct involvement in the provision of organisation's products and services. Organization's staff's effective performance is established by social intricacy which makes it hard for rivals to duplicate as stated by Jiang et al (2012). In non-profit organisations, the management structure includes the management board, executive committees, salaried employees and various volunteers. In a more competitive environment, the organisation's structure is highly expected to hinder or help in having better operations. For instance, when the firm's framework has most level of management, the rate of decision making is basically reduced. Volunteers form the major normal part of the non-profit firms, while it is hard to recruit volunteers, the organisation can establish strategies and enable flexibility as a way of appointing the required volunteers ((Stonehouse \& Pemberton, 2002). The management strategies used by the firm's executives are also expected to have a great impact on the staff morale. As defined by Wang, Walker \& Redmond (2007) more contemporary forms of management that that engages its staffs is expected to have better connection and performance of staffs. The firm's internal environment can as well influence the operations and the morale of staffs. A more pleasant working environment can be of great importance in enhancing the staff's operation. Availability of adequate resources in terms of specific tools and equipment required as well help in enhancing the activities of staffs. Thus, inefficiency and inadequate resources are expected to hinder the performance of staffs and a subsequent decline in the customer satisfaction (Welter, 2003). An organisation's financial stability on the other hand, influences its internal environment. Despite effective internal factors, it may be hard for firms with limited cash to effectively execute its strategic plans. In case firms have financial struggles its definite that all their services will be affected.

This is one of the organization's main steps of strategic management which includes analyzing the information, formulating a strategy, strategy implementation and evaluating and control. Strategy Implementation process varies from one Organization to another depending on factors such as the type of business that the firm is engaged in and the structure of its management. Pearce et al. (2007) stated that strategy implementation is the performance or the enactment stage of an organization's strategic plan. Swayne et al (2008) provides that strategic implementation defines the firm's path of operations. Strategic Implementation sets organization direction and via a common vision comprehension, strategic objectives provides a template for everyone in the faculty to make decisions consistently which makes the organization to move towards envisioning future. Beckham (2002) defines true strategy as a getting some point in the future in face of resistance and uncertainty from a point in the present.

Evashwick and Evashwick (1988), incorporated mission and vision concept, explaining strategic Implementation as the process of assessing the nature changes to create a future vision; to determine on how the organization fits into the nature that it is anticipated based on its mission institution weaknesses and strength; and then setting in motion an action plan according to the faculty position. Defining the organizational objectives is the first step; these objectives might 
have single or several goals; the organisation business vision is described by the mission statement that includes the long-term values and function and goals that are visionary and will guide in pursuing the opportunities in future. In guide of the business vision the leader of the firm can explain strategic goals and finance that are measurable. The objectives of the finance are associated to the position of the business firm that may comprise measures such as reputation and market share. Nature scanning involves the second step which includes analyse of the firm internally, firm industry analysis (task environment) and external environmental micro. From the environmental scan information given, the opportunities that it has identified should match with its strength in addressing external threats and weaknesses. For attainment of profitable superiority, organisations attempt to develop a competitive advantage over its competitors. Differentiation of cost determines the competitive merits; Michael Porter established three strategies from which a firm chooses, they include focus strategy, cost, differentiation strategy and leadership strategy (Howard, 2007).

The strategy used could be different in various ways and have different requirements regarding many aspects in the firm's organizational structure. The second implementation challenges are factors associated to the organizational structure as per to Helde et al (2012) study. Drazin et al (1984) stated that an alignment of strategy with the structure of the organization is a significance pre-requisite for a corporate business implementation success (Noble, 1999). They noted that competitive nature is dynamic thus requires adjustment to the structure of the organization. If a firm's leadership lacks strategies it may have poor performance, and this can be a major competitive disadvantage for the organisation. The organizational structure which wrong prevents successful implementation of strategies plans. Structures in the organization aims at maximising the efficiency and success of the organization. Organizational structure which is effective will facilitate relations in working between many organization sections. It will retain command whilst and order promoting creativity and flexibility. A firm's organizational structure exists in order to make decision making process easier. A typical organizational chart shows a hierarchy of authority from the Chief Executive Officer to the middle level managers then the junior staff; the leadership set's the goals and direction of an organisation. According to Shung (2000) the supporting managerial levels under the executive are important in ensuring objectives in their areas of departments or responsibility, that are attained in the order of appropriate flow of information from the top management.

The Kenya Medical Research Institute Welcome Trust Research Programme is based on the KEMRI Centre for Geographic Medical Research-Coast, its major functions are financed by the Wellcome Trust. KWTRP conduct integrated epidemiological, laboratory, social and clinical research with finding feeding into international hand local health policies. Research platforms includes a demographic surveillance system that covers a quarter of the million residents, state-ofthe-art laboratories, a vibrant community engagement programme, hospital surveillance, a partnership with Kilifi County Hospital, clinical trials facility and a dedicated training facility. KWTRP mission is to deliver high quality research which is relevant global health and to build local capacity for undertaking research while its vision is the establishment of long-term sustainable capacity for research in human health. KWTRP has a five-year strategy that runs from 2016 to 2021. The Programme has delivered international competent research and capacity building for the last 26years. The core funding was renewed by trust for its 5-year cycle from October 2016. The Strategic Implementation is on the process review for the next five years. The scientific topics together draw investigators from different disciplines to work on areas of high priority and enhance the rapid dissemination and findings uptake into practise and policy. The work within and between topics is highly inter-disciplinary and relations between topics is 
common. KWTRP has different organisational resources at its disposal including Human Resource, Technology, Financial, Donor relation and stakeholder Community. The study sought to investigate how three of these resources influence the implementation of the institutes strategic Plan.

\section{Statement of the Problem}

Strategic implementation is the enactment stage of strategic management process, this makes it the most critical phase as without its proper execution an organisation will not have a solid foundation. Although planning and formulating a strategy is an involving task for any management, implementing the strategies within the organization is even more difficult (Hrebiniak, 2006), there are several factors that affects the process by which strategic plans are turned into organizational action; best formulated strategies are not usually met if they are not properly implemented. Akeyo (2016) asserts that supportive budgets and adequate resource allocation is considered a priority during the strategic plan implementation, the support given to project managers determines the success of working through others, projects should be implemented in line with organization's strategy and project managers should be well informed of the organization's strategy. This means that the human resource is an important element during design and implementation of strategic plans, Thompson, et al. (2011). Most NPOs in Kenya have not fully embraced the use of strategic plans due to the difficulties involved in development of strategic plans or not engaging professionals in developing and implementing them. Strategy implementation at KWTRP has equally faced numerous challenges ranging from limited resources, limited capacity, poor planning, externalities and government policy among other regulatory agencies and political interference. The premier research organization has over the years developed 5-year strategies most of which are not implemented to a significant percentage with the last been 2010-2015 which according to the management was implemented to a tune of $57 \%$. This indicates that the firm has not been up-to-date in strategy implementation. This study will seek to narrow the gap on what factors have mainly affected the process and to assist it in ensuring that the current strategy implementation process can be improved or re-evaluated for better results after the five years.

Scholars in Kenya have undertaken studies on strategic plan in organizations. Among the local studies include Kasimbu (2007) who focused on strategic plan development among Non-Profit Organizations (NPOs) in Nairobi where the study established that community determines the nature of operations and the quality of products and services offered by NPOs and that sponsors influence on the budget allocation while the government plays a supervisory role and creation of conducive environment for the NPOs to work in. Kisinguh (2006) who laid focus on stakeholders' involvement in the strategic plan implementation in public institutions in Kenya established that most NPOs never put premium on strategic development. Bariti (2009) whose focus was on management perception of strategic plan implementation in Kenya and Gekonde (2011) who assessed the role of stakeholders in determining the content of the strategic plan at Nature Kenya where they established that stakeholders never put emphasis on strategic plan implementation. While all these studies have availed evidence of strategic plan implementation in various organizations, the researcher has not come across a study with a specific focus on how organizational resources affect Strategy Implementation at a research organisation such as KWTRP which operates in local and international environment with government and donor management input. This study therefore sought to fill the identified research gap by exploring how organizational resources influence strategic plans implementation in KWTRP in Kenya. 


\section{Objectives of the Study}

The general objective of the study was to establish the influence of organizational resources on Strategy Implementation at Kenya Medical Research Institute - Wellcome Trust Research Programme in Kenya.

The study will have the following specific objectives:

i. To determine the influence of human resources on strategy implementation at KWTRP

ii. To examine the effect of financial resources on strategy implementation at KWTRP

iii. To assess the influence of technological competence on implementation of strategic plan at KWTRP.

\section{Theoretical Review}

This study was guided by two theories; the Resource-based view theory of the firm and organization learning theory.

\subsection{Resource Based View theory}

This theory was postulated by Penrose in 2009. The theory argues that firms perform differently due to their unique internal and external resources that may not be imitated or transferred. The theory is based on the concept of economic rent and the view of the organisation as a collection of capabilities. This view of strategy has a coherence and integrative role that places it well ahead of other mechanisms of strategic decision making. Traditional strategy models, such as Michael Porter's five forces model, focus on the organisation's external competitive environment. Most of them do not attempt to look inside the organisation. In contrast, the resource-based perspective highlights the need for a fit between the external market context in which an organisation operates and its internal capabilities. This theory emerged in 1980s and 1990s, and it aided to achieving competitive advantage. Wenerfelt's book (1984) suggests that the firm's resource profile determines performance while having resources difficult to imitate influences the source of superior performance. According to Barney, (1991) Possession of certain key resources and effectiveness in deploying these resources in chosen markets can aid firms in achieving sustained competition as proposed by RBV. It is further stipulated that attributes of a firm's assets and their rare, valuable capabilities influence the organisation's competitive advantage and performance.

According to Baker and Sinkula, (2005) the RBV of the firm proposes that firm specific resources and capabilities affects Strategy Implementation. Key RBV determinants as stated by Grant (1991) are levels of resilience, replicability, limpidity and transferability, Amit, and Schoemaker (1994) argue that complementarity, shortage, non-tradability, exclusivity, limited substitutability, appropriability, resilience and similarity in planned industry factors constitute key firm resources. According to Day (1994), intangible assets for example market orientation, managing of knowledge and learning of an organization gives firms a chance to initiate abilities that improve competitive advantage causing improved market performance. The Resource-Based View considers internal capabilities in the formulating strategy to achieve a sustainable advantage in its markets and industries. If we see the organization as made of resources and capabilities which can be configured to provide it with competitive advantage; then its perspective does indeed become inside-out. In other words, its internal capabilities determine the strategic choice it makes in competing in its external environment. In some cases, a firm's capabilities may allow it to create new markets and add value for the customers. Where organizations capabilities are seen paramount 
in the creation of competitive advantage it will pay more attention to the configuration of its value chain activities because it will to identify the value chain activities which provide it with competitive advantage. This theory will be used to establish how diligent use of organizational resource will improve implementation of strategic plans among organizations in Kenya especially the KWTRP.

\subsection{Learning Organization Theory}

As demonstrated by the models which was established by Easterly-Smith, Crossan and Nicolini (2000), an organization which aid in learning its members and continuously enhances itself reflects a learning organization. This is highly established once modern firms face various issues. The major features for an $\mathrm{n}$ organisation to have sustainable competitive advantage in a turbulent business environment are business personal efficient. As demonstrated by Serenko, Bontis and Hardie, (2010) firms need to emulate societies by making staffs be committed thus work harder. Learning organisation are defined by the ability of the organisation too always involve its members in a continuous transformation. An organisation that embrace a continues learning activity have a very competitive environment as they adopt key strategies of handling possible issue that arise form modern organisation in the business environment. As demonstrated by Serenko, Bontis \& Hardie (2010) learning organisation is a composition of five major features including shared visions, mental models, personal mastery, team learning and systems thinking. The process of learning organisation greatly helps in encouraging firms to move to a more interconnected strategy of thinking.

The model provides that, to effectively have a competitive environment, firms need to have changes on the actions and objectives (Janz \& Prasarnphanich, 2003). Though, the process of learning, the organisation needs to establish a conscious decision to change activities in response to $\mathrm{n}$ a change in conditions. The process of organizational learning contains major similarities to cognitive research as the initial learning occurs on personal levels: though, it never becomes organizational learning until information and activities are shared, stored in the organizational memory in manner that it can be transmitted and accessed (Cha, Pingry \& Thatcher, 2008). Learning is a process, with acquisition being the initial phase of learning. The organisation attains a "memory of valid action- outcome that connects, the business environment in which it's valid, the possibilities of the outcomes and the probability's uncertainty. The action outcome connects are acquired through benchmarking, grafting and experimental. Notably, an organization's practices may and can change in based on the business environment changes. Ultimately, more successful organizations scan their operational environments as a way of determining when change is key, this as a result presupposes that they have an informed consent on the environment in which they operate in and can easily adopt to any changes (Hult,Tomas, Hurly, Giunipero \& Nichols, 2000).

The second section in the process of learning is the interpretation phase. Firms should always be observing and compare actual to the anticipated outcomes to ensure that efficiency and strategies are established to ensure the organisation attains its expected outcomes. Various theories provide that there must be action for learning to occur, but others argue that what matters is the expansion knowledge base. The third phase of organizational learning in the action rather the adaptation phase. An organization uses the interpreted knowledge in choosing most effective action outcomes links effective to the new operational environment. The process enhances the updating of the organization's knowledge base to include key action outcome that would of positive impact to the organization's outcomes (Serenko et al., 2010). Organizations (Debowski, 2006) have had various 
experiences on the way they operate due to the regularly changing business environment and changes in technology. This has demonstrated the importance of organisation to hold knowledge that is of positive effect to the firm's success. Any firm which desires to sustain its competitive advantages involves learning faster and better from the failures. In a learning organization, different ideas and information are infused by regular scanning the business external environments, recruiting new and competent individuals and the specialists required (Kinicki \&Kreitner, 2009). Moreover, employees' mistakes should be viewed as potential sources of new ideas and ways of doing things (Marquardt, 2011). As described by Debowski, (2006) firms seeks to employ different authoritative sources such as the firm's held knowledge in enhancing its operations. More over Kinicki \& Kreitner (2009) demonstrates that new organizational ideas are a prerequisite for the learning organization.

\section{Empirical Review}

Ngumbi (2019) A study conducted in Baringo County on the influence of organizational resources in strategy implementation in administrative police indicated that human resources remarkably influence strategy implementation. The relationship between the station commanders and junior officers was notably good. Continuous Professional Development courses were offered to targeted officers in the county for increased capacity level. Officers welfare was rightly addressed by the senior management. Alexander (2015) study on implementation of strategies in corporations revealed that over half of the corporations studied experienced human resources challenges, the employees involved had insufficient skills to perform their jobs while (Govindarajan, 2009) noted that, the effectiveness of strategy implementation was at least in part affected by the quality of staff involved in the process. Lam (2017) argued out that the civil service morale has declined a factor that would largely affect the execution of NPM methods. From the allegations, it would be established that the public sector reforms would be expected to be of no success to the public servants (Lam 2017). Yang (2008) stated that, executors of strategies comprises of the organisation key executive management both from the top, lower, middle and non-management. Viseras, Baines, and Sweeney's (2005) provides that, implementation of strategy success depended basically on the personnel undertaking the project management. While Harrington (2006) findings revealed that, a higher a level in total organizational involvement during strategy implementation lead to positive effects on the level of implementation success hence leading to firm profits and overall firm success.

As the organisation Human Resource grows its traditional administrative role, it has been of great importance on the firm's growth. To effectively align the firm's Human Resource to the firm's approach, it first requires so be grouped in that it effectively plays a crucial role in the strategic Implementation of a firm. It's basically a human capital which leverages all other sectors of a firm. Thus, the Human Resource department must ensure that the organization's human asset is efficiently aligned to the organization's strategy. Capitalizing on the leverage, firm should embrace a new perspective of Human Resource (Becker, \& Huselid, 2001). Human resource requires to measure its effect on the firm's strategy and its efforts on building initiatives to effectively manage the firm's growth. Specifically, Human Resource should measure the firm's alignment, leadership and culture (Norton, 2001). Examining the issues offers a strategy for illustrating the key drivers of a firm's strategy. Human resource is highly involved in accessing the efficiency of these drivers in determining the success of an organisation. Human Resource is perceived as one of the key strategic supportive elements to the firm's growth. Through the tool, organisation can carry their Human resource activities more effectively by ensuring that there is efficiency on staff 
involvement, polices are adhered to, there is culture development and enhances workforce flexibility and empowerment (Schuler and MacMillan, 1984; Schuler, 1992).

HR is one of the most crucial part of the organization's assets. To efficiently align the organisation's HR to the firm's strategy, the organisation must involve the executive management (Freedman, 2004). The fundamental premise underlying the Strategic HRM is that firms embracing an approach needs HR practices which are relatively different from the ones needed by firms embracing alternative approaches (Dyer, 1984a, 1984b). In this primary assumption is accurate, then high variation in HR practices across the firms needed to be illustrated by the firms' approaches and firms that have a greater congruence between the firm's strategies and HR practices. For instance, Schuler and Jackson (1988) and Arthur (1992) provides that firms following different approaches uses various HR practices. Various researchers have also illustrated that HR practice scan negatively affect the organization's outcomes like productivity rates and the firm's profit rate (Arthur, 1994; Gerhart \&Milkovich, 1990; Huselid, 1993, 1995. Human Resource Management is highly focused in managing the organization's staffs towards attaining the firm's objectives (Wright, McMahan, and McWilliams, 1994). The process is attained via the process of attracting, selecting the most competent individuals. This is followed by motivations and efficient strategies of compensations which are aimed at improving the staff's morale towards accomplishing their goals and reducing the rate of employee turnover (Macky and Johnson, 2013).The HRM personnel as well plays a key roles in ensuring that the organization's training and development needs are attained as it also helps in both individual and organizational learning (Delahaye, 2010) and makes sure that the firm complies with the set legislation, policies and procedures concerning employee management (Macky and Johnson, 2013).

Within the organizational setup, people are refereed as organizational assets that help in attaining the firm's objectives. As a result, human resources are valued as one of the most crucial assets to the firm's operations. The focus on human resources has been a new mantra for organizational success. The latest theory in HRM provides that people are an "inimitable" organizational asset. People skills and workforce is one of the organizational assets that firms cannot compete with and would not imitate. A more skill, competent and effective workforce enhances the firm's performance by e contributing to the client fulfilment, enhanced productivity and enhanced public image of the firm (Wernerfelt, 2014). The organisation human resource positively influences the activities of a firm as it enables the firm's resource optimization, efficiency and enhances continuous improvement (Wernerfelt, 2014).And thus, firm stake time in nurturing and developing human capital in knowledge forms, capabilities and attitudes as well as inter personal relationships and thus making it hard for rivals to duplicate (Becker and Huselid, 2012). According to Pfeffer (2014), human resource has been key to an organization's nature of operations (Myloniet al., 2014). Under a knowledge economy, for instance, the HR is valued as a key strategic framework, which is necessary to the firm's profit growth as well as a tool to the firm's sustainability. This reflects on the fact that human resource is a strategic tool that enhances the firm's sustainability (Jackson and Schuler, 2010). Huselid (1995) looked at HR practices of high-performance companies and established that indeed attracting and selecting the right employees helps to increases the employee productivity, while at the same time boosting the performance of the organization and thus contributes to reduced turnover.

A study done by Muchemi (2014) on strategy implementation found that inadequate funds on their own are a major factor affecting the implementation of strategic plans in public organizations; Successful implementation of a strategy requires enough capital investment. Kaplan and Norton 
provide that "a strategy refers to established hypothesis concerning a specific impacts and cause. To effectively contribute to the set organizational plan, an organisation must grasp the major cause and impact correlation that connect strategic drivers and Critical Success factors to strategic results. The connection greatly results from a somewhat subconscious procedures which basically takes place once there is a synthesizing mind and selects to be immersed in both the action and the data. Covey categorised the procedure as continuous "sharpening of the saw." There is a paucity of studies employing the RBV approach in financial resources and competitive advantage (Lockett and Thompson, 2011), with a few notable exceptions.

Westhead et al., (2011) employ the RBV to explain the role of financial resources and competitive advantage. Kelleher and Reinl (2009) adopt the RBV approach to examine financial management and competitive advantage. Barney et al., (2011) state that there is significant scope for additional RBV studies in the field of economics and finance, particularly empirical work. The RBV would be more crucial to the sectors of financial resources as its important on the intangible resources of the experimental knowledge and managerial efficiency in establishing competitive advantage. The resources are particularly crucial as resources constraints basically preclude procurement of the talent outside the organization. According to Wernerfelt (2014), Lockett and Thompson (2011) they all highlight that financial resources have a direct relation to competitive advantage as well as the "past activities of the firm", which is especially true in respect of managerial and organizational capabilities. This may be particularly true in the case of firms, which typically grow from start-up or are developed by serial entrepreneurs. The managerial skills garnered during their entrepreneurial journey are greatly valuable and form the core of the firm's competitive advantage.

Lockett and Thompson (2011) notes that financial resources are important in the development of human resources and are both key for sustainable strategy implementation of organizations. As presented form past empirical researchers for organizational and entrepreneurial learning provides that the decision on investments in organisation is based on experimental learning in comparison to the formalised techniques( Ekanem and Smallbone, 2014).As further stated by Deakins et al (2013) experience is relatively crucial as it offers time of recognizing opportunities, establish contact and experience and learning on the way of accessing and interacting with financial providers such as venture capitalist and bank executives. As much as some of the research provide that small number of financial managers use the resulting knowledge in a proactive manner to establish competitive advantage (Matlay, 2010) various researchers did express that as organizations shift from a higher-level learning structure, its linked by competence enhancement which can result to higher organizational ability (Deakins and Freel, 2013). Although some studies report that only a small number of financial managers employ the resulting knowledge in a proactive way to build competitive advantage (Matlay, 2010), other studies find that as firms move from a higher-level learning style, this is accompanied by competence enhancement that can lead to greater organizational capability (Chastonet al., 2011) and hence sustained competitive advantage.

A study by David (2013) notes that technology is one of the critical resources in an Organization which when properly utilized leads to successful implementation of organizational strategy. Efficient attainment of development strategy needs a defined understanding of the strategic Implementation on the extent of organizational technology. In situations where the approach implemented exceed the limitations, the need for more sources of capital is self a strategic factor and an iterative process of valuing strategic alternative begins. The disconnection between the technological progression and consumer needs expresses that technology has no effect on strategic 
performance of an organisation (Shaukat, 2009). He further provides that, there exist a direct correlation between technology and performance without considering any mediation, a factor which demonstrates the existence of a gap that the present research tries to fill by mediating the connection with competitive advantage while maintaining technology as an independent variable. Rhee et al. (2010) argues that to invest in research and development calls for evaluation of advantage and cost before making the decision whether to adopt or invest in technology. In the study it is argued that technology is linked to greater firm innovativeness. The conclusion of the study was that there is a strong positive relationship between technology and performance in SMEs in Korea and hence strategic implementation.

\section{Conceptual Framework}

A study's conceptual structure is fundamental frame that entails specific blocks that reflect on the observational, analytical and experimental issues of a procedure or systems being conceived. Conceptual framework of a study consists of independent and dependent variables and their interconnection showing the structure to achieve the specific anticipated results. The Independent variables of the study were human resources, financial resources, and technological competence while and dependent variable was strategy implementation.

Independent Variables

Organizational Resources
Dependent Variables

Strategy Implementation

\section{Human Resources}

- Staff qualification and skills

- Decision making

- Staff Experience in years

Financial Resources

- Sources of funding

- Volume of funding

- Accountability

- Operational efficiency

Technological competencies

- Innovations

- Research and development

- Capacity

Figure 1: Conceptual Framework

Source: Researcher, 2018

\section{Research Methodology}

The research employed a descriptive survey research design. Orodho (2003) states that a descriptive research design is employed in preliminary and exploratory studies to enable the

Strategy Implementation

- Programme objectives

- Budget compliance

- Time schedule adherence

- Beneficiary satisfaction 
researcher to effectively attain information and analyse and interpret more effectively. The population of the study was the management staff at KWTRP in Kilifi County, Kenya who were 60 according to the KWTRP (2018). The target population for the study was therefore 60 respondents. Semi-structured questionnaires were employed in gathering the required data. A pilot testing was conducted using few populations in determining the efficiency of the questionnaires also as a way of determining the accuracy and validity of the gathered data. Self-completion questionnaires were employed using open and closed ended questions. All this was used in getting in depth answer that was enhanced the attainment of objectives of the study. Once the data was collected, it was edited to ensure it was complete and it's consistent. The quantitative data was then analysed through descriptive statistics using SPSS and presentation made through standard deviations, percentages, frequencies and means. The analysed data was then displayed through the charts, prose forms and graphs, content analysis was employed in testing data which was qualitative. Additionally, the study conducted a multiple regression analysis.

\section{Data Analysis Results}

Table 1: Model Summary

\begin{tabular}{|c|c|c|c|c|c|c|c|c|c|}
\hline \multirow[b]{2}{*}{$\begin{array}{l}\text { Mod } \\
\text { el }\end{array}$} & \multirow[b]{2}{*}{$\mathrm{R}$} & \multirow[b]{2}{*}{$\begin{array}{c}\mathrm{R} \\
\text { Square }\end{array}$} & \multirow[b]{2}{*}{$\begin{array}{c}\text { Adjusted R } \\
\text { Square }\end{array}$} & \multirow{2}{*}{$\begin{array}{l}\text { Std. Error } \\
\text { of the } \\
\text { Estimate }\end{array}$} & \multicolumn{5}{|c|}{ Change Statistics } \\
\hline & & & & & $\begin{array}{l}\text { R Square } \\
\text { Change }\end{array}$ & $\begin{array}{c}\mathrm{F} \\
\text { Change }\end{array}$ & df1 & df2 & $\begin{array}{c}\text { Sig. F } \\
\text { Change }\end{array}$ \\
\hline 1 & $.824^{\mathrm{a}}$ & .679 & .659 & .876 & 679 & 33.783 & 3 & 48 & .000 \\
\hline
\end{tabular}

Source: Research Data (2019)

The results in Table 1 show that $0.659(65.9 \%)$ as the value of adjusted R square showing the extent to which strategy implementation at KWTRP is determined by the human resources, financial resources and technology competence. Therefore, the remaining percentage $(34.1 \%)$ should be studied to determine how other factors influence the implementation of strategies at KWTRP.

Table 2: Analysis of Variance

\begin{tabular}{|rl|r|r|r|r|r|}
\hline Model & & Sum of Squares & df & Mean Square & F & \multicolumn{1}{|c|}{ Sig. } \\
\hline 1 & Regression & 77.818 & 3 & 25.939 & 33.783 & $.000^{\mathrm{a}}$ \\
& Residual & 36.856 & 48 & .768 & & \\
Total & 114.673 & 51 & & & \\
& & & & & \\
\hline
\end{tabular}

\section{Source: Research Data (2019)}

The value $0.000^{\mathrm{a}}$ shows the significance level is less than 0.05 showing a statistical significance of the model on how independent variables studied influenced the implementation of strategies at KWTRP. The results in Table 4.8 also indicate that $\mathrm{F}$ calculated value is greater than the value of F tabulated (33.783> 25.939) at 5\% significance level confirming the significance of the model.

\section{Table 3: Coefficients}




\begin{tabular}{|c|c|c|c|c|c|c|}
\hline \multirow{2}{*}{\multicolumn{2}{|c|}{ Model }} & \multicolumn{2}{|c|}{$\begin{array}{c}\text { Unstandardized } \\
\text { Coefficients }\end{array}$} & \multirow{2}{*}{$\begin{array}{c}\text { Standardized } \\
\text { Coefficients } \\
\text { Beta }\end{array}$} & \multirow[b]{2}{*}{$\mathrm{t}$} & \multirow[b]{2}{*}{ Sig. } \\
\hline & & $\mathrm{B}$ & Std. Error & & & \\
\hline \multirow[t]{4}{*}{1} & (Constant) & 0.524 & 1.075 & & 1.790 & .000 \\
\hline & Human resources & 0.643 & .268 & 5.275 & 2.395 & .001 \\
\hline & Financial resources & 0.525 & .344 & 1.367 & 2.981 & .004 \\
\hline & $\begin{array}{l}\text { Technology } \\
\text { competence }\end{array}$ & 0.855 & .087 & 3.882 & 9.772 & .000 \\
\hline
\end{tabular}

\section{Source: Research Data (2019)}

The findings in Table 3 revealed that holding independent variables constant (human resources, financial resources and technology competence) to a constant zero, the implementation of strategies at KWTRP would be at 0.524 factor, a unit increase in human resources would lead to a unit increase in the implementation of strategies at KWTRP by a factor of 0.643 , a unit increase in financial resources would lead to a unit increase in the implementation of strategies at KWTRP by factor of 0.525 and a unit increase in technology competence would lead to a unit increase in the implementation of strategies at KWTRP by a factor of 0.855 . The established regression equation was as follows; $\mathrm{Y}=0.524+0.643 \mathrm{X}_{1}+0.525 \mathrm{X}_{2}+0.855 \mathrm{X}_{3}$; Where $\mathrm{Y}=$ Strategy implementation, $\mathrm{X}_{1}=$ Human resources, $\mathrm{X}_{2}=$ Financial resources, $\mathrm{X}_{3}=$ Technology competence. The results in Table 3 further indicate that technology competence had the highest influence on strategy implementation at KWTRP as shown by a factor 0.855 followed by human resources with a factor of 0.643 and financial resources with a factor of 0.525 . The relationships $(\mathrm{p}<0.05)$ was all significant with human resources $(t=2.395, \mathrm{p}<0.05)$, financial resources $(\mathrm{t}=2.981, \mathrm{p}<0.05)$ and technology competence $(\mathrm{t}=9.772, \mathrm{p}<0.05)$. Human resources have a greater correlation with the organization's superior performance as they have a direct involvement in the provision of organisation's products and services. Organization's staff's effective performance is established by social intricacy which makes it hard for rivals to duplicate as stated by Jiang et al. (2012). Lockett and Thompson (2011) support these findings by noting that financial resources are important in the development of human resources and are both key for sustainable strategy implementation of organizations. David (2013) who notes that technology is one of the critical resources in an organisation which when properly utilized leads to successful implementation of organizational strategy.

\section{Conclusions}

On human resources, the study concludes that an organization's workers are the real assets. These are the ones who consistently contribute to an organization's efficient functioning. Employees strive to deliver their best level within the stipulated time frame and meet the set goals. The organization's success depends on how effectively employees conducts their tasks. On financial resources, the study concludes that proper allocation of financial resources allows managers to put together more productive and efficient workplace teams and enables them to assess their schedules and predict the availability of resources in real time effectively. Financial resources allow the organization to set and track clear and measurable strategic financial goals in a coordinated manner enabling the organization to function effectively and efficiently during strategy implementation process. The study concludes on technology competence that IT lies in its ability to streamline interaction both internally and externally. One of the essential benefits of software expertise is its 
potential by promoting strategic thinking and knowledge transfer to improve the competitive advantage of an organization in the marketplace. Technology expertise has provided the organization with unprecedented access to information on successful execution of the strategy.

\section{Recommendations}

The study suggests that the organization incorporate top-down and bottom-up plan development on human resources in order to gain input from the lower management tier. Involve workers in formulating strategies in order to significantly increase their contribution to executing a strategy. Management should clarify the plan during informal meetings and ask staff to comment on it to give employees a sense of ownership and inspiring them to execute strategies properly. The study advises that the leadership of the organization should provide enough financial resources to execute strategies effectively. For each assignment within the plan, periodic cost estimates are important so that the use of financial resources can be made as efficiently as possible. On technology competence, the study suggests that management seek more support for technical ways of executing strategies by having clear and articulated career paths for their staff, leave room for improvement to ensure cohesion of efforts in support of the implementation of the strategy.

\section{References}

Abu, B., Fariza, H., Hartini., Filzah, I., \& Hisham, D. (2009). Distinctive capabilities and strategic thrusts of Malaysia's institutions of higher learning. International Journal of Marketing, 1(2), 20-25.

Abuya, B. (2011). Strategy Implementation Challenges at Action aid Kenya. Unpublished MBA project. University of Nairobi.

Adner, R. \& Helfat, C. E. (2013). Corporate effects and dynamic managerial capabilities. Strategic Management Journal, 24(1), 1011-1025.

Ahuja, K. \& Katila, P. (2014). Building organizational capability: Your future, your business, Journal of Strategic Management, 11(8), 5-16.

Ainuddin, R. A., Beamish, P. W., Hulland, J. S., \& Rouse, M. J. (2007). Resource attributes and firm performance in international joint ventures. Journal of World Business, 42(3), 47-60.

Altindag, E. Zehir, C. \& Acar, A.Z. (2010). Strategic Orientations and Their Effects on Firm Performance in Turkish Family Owned Firms, Journal Eurasian Business Review, Vol. 1. p. 18-36.

Akeyo, Nancy A, (2016) Challenges of Strategy Implementation in Non-Governmental Organizations in Migori County, Kenya. Unpublished MBA project, University of Nairobi

Baker, W.E. \& Sinkula, J.M. (2005) Environmental marketing strategy and firm performance: Effects on new product performance and market share

Journal of the Academy of Marketing Science 33: 461

Bariti, G. (2009). Management perception of strategic plan development at Nature Kenya Unpublished MBA project, University of Nairobi

Barney, J. (1991). Firm resources and sustained competitive advantage. Journal of Management, 17(1), 99-120.

Barney, J. (1995). Looking inside for competitive advantage. Academy of Management Executive, 9(4), 49-61.

Barney, J. (2001). Is the resource-based view a useful perspective for strategic management research? Yes. Academy of Management Review, 26(1), 41-56. 
Barney, J. B. (2007). Gaining and sustaining competitive advantage (3rd ed.). Upper Saddle River, NJ: Pearson Education.

Barrett, D. J. (2012). Leadership communication. New York, NY: McGraw-Hill.

Bengtsson, N. \& Kock, M. (2010). New venture growth: A review and extension. Journal of Management, 36(3), 926-950.

Besanko, D., Dranove, D., Shanley, M., \& Schaefer, S. (2014). Economics of Strategy (4th ed.). Danvers: MA: John Wiley and sons.

Bowen, D. E. \& Ostroff, C. (2014). Understanding HRM-Firm performance linkages: The role of the strength of the HRM system. Academy of Management Review, 29(2), 203-221.

Chang, P. L. \& Chen, W. L. (2012). The effect of human resource management practices on firm performance: Empirical evidence from high-tech firms in Taiwan. International Journal of Management, 19(4), 622-38.

Chandler, G. \& Hanks, S. (1994). Market attractiveness resource-based capabilities: Venture strategies and venture performance. Journal of Business Venturing, 9(1), 331-349.

Chaharbaghi, K. \& Lynch, R. (1999). Sustainable competitive advantage: Towards a dynamic resource-based strategy. Management Decision, 37(1), 45-50.

Charlene, B. (2009). The JIT challenges for maintenance. The Magazine Of Manufacturing Performance, September-issue, 1, 34-35.

Cheng, Y. H. \& Yeh, C. Y (2007). Core competencies and sustainable competitive advantage in air-cargo forwarding: Evidence from Taiwan. Transportation Journal, 5(2), 34-37.

Cheng, L. \& Grimm, C. (2006). The application of empirical strategic management research to supply chain management. Journal of Business Logistics, 27(1), 1-57.

Cole, G. A. (2004). Organizational Behaviour: Theory and Practice. London: Thomson Learning.

Cooper D. R., C. W. Emory, (1995) "Business Research Methods," 5th Edition, Irwin.

David, F.R. (2013). Strategic management: A competitive advantage approach, concepts and cases, 14th ed. Essex, England: Pearson Education, Inc

Day, G. (1994). The capabilities of market-driven organizations. Journal of Marketing, 58, 37-52.

DeNisi, A. S., Hitt, M. A. \& Jackson, S. E. (2013). The Knowledge Based Approach to Sustainable Competitive Advantage. New York, NY: Oxford University press.

Fiol, C. M. (2011). Revisiting an identity-based view of sustainable competitive advantage. Journal of Management, 27(2001), 691-699.

Gekonde, D. (2011). The role of stakeholders in determining the content of the strategic plan at Nature Kenya. Unpublished MBA project, University of Nairobi.

Goh, S. C. (2003). Improving organizational learning capability: Lessons from two case studies. The learning Organization, 10(4), 216-227.

Goh, S. (2014). Conceptualizing knowledge creation: A critique of Nonaka ${ }^{\text {ee }}$ theory. Journal of Management Studies, 43(7), 1415-1436.

Hitt, M. H. (2014). A Mid-Range theory of the interactive effects of international and product diversification on innovation and performance. Journal of Management. 23(4), 297-326.

Huselid, M. A. (1995). The Impact of Human Resource Management Practices On Turnover, Productivity, And Corporate Financial Performance. Academy of Management Journal, 38(3), 635-672

Hrebiniak, L.G (2006). Obstacles to Effective Strategy Implementation, Organizational Dynamics, 35, 12-31 
Janz, B. D. \& Prasarnphanich, P. (2003). Understanding the Antecedents of Effective Knowledge Management: The Importance of a Knowledge-Centered Culture. Decision Sciences, Vol. 34, No.2, Pp. 351-385.

Johnson, G. \& Scholes, K. (2012). Exploring Corporate Strategy (6th Ed.). Harlow, EX: Prentice Hall.

Jiang, K \& Lepak, David \& Hu, Jia \& Baer, Judith. (2012). How Does Human Resource Management Influence Organizational Outcomes? A Meta-Analytic Investigation of Mediating Mechanisms. The Academy of Management Journal. 55. 1264-1294.

Johanson, J. V. (2008). The internationalization process of the firm: A model of knowledge development and increasing foreign commitment. Journal of International Business Studies, 2, 23-32.

Jaworski, B. J. \& Kohli, A. K. (1993). Market orientation: antecedents and consequences. Journal of Marketing, 57, 53-60.

Kabanof, P. \& Brown, C. (2008). Resourcing Small and Medium Sized Enterprises. Berlin DE: Springer-Verlag.

Kasimbu, J. M. (2007). The extent of Stakeholder Involvement in Strategy Formulation Among Non-Governmental organisations within Nairobi. Unpublished MBA Project, School of Business University of Nairobi, Kenya.

Kisinguh, F. (2006). Shareholders involvement in the strategic plan development in public organizations in Kenya. Unpublished MBA project, University of Nairobi.

Kombo, K. D. and Tromp, L. A. D. (2006). Proposal and thesis writing: An introduction. Nairobi: Pauline Publications Africa.

Lockett, A. \& Thompson, S. (2011). The resource-based view and economics. Journal of Management, 2, 27-33.

Makadok, R. (2001). Toward a synthesis of the resource-based and dynamic-capability views of rent creation. Strategic Management Journal, 22(5), 387-401.

Muchemi, Doreen W. (2014) Strategy implementation practices at the Kenya Post Office Savings Bank. Unpublished MBA project. University of Nairobi

Mugenda, O. M. \& Mugenda, A. G. (1999). Research Methods. Nairobi, KE: Act Press.

Mugenda, O. M. \& Mugenda A. G. (2003). Research Methods: Quantitative and Qualitative Approaches. Nairobi, KE: Act Press.

Murithi, A. (2011). Factors Contributing to Sustainable Competitive Advantage in Telecom Business Organizations: A Case Study of Safaricom Limited. Unpublished Thesis, United States International University.

Ngumbi, (2019). Organizational resources and strategic plans implementation in administration police service in Baringo county, Kenya. European Journal of Business and Strategic Management, [S.1.], v. 4, n. 4, p. 14 - 33

Ong, J. W. \& Ismail, H. B. (2008). Sustainable Competitive advantage through information competence: Resource-based view on small and medium enterprises. Technology Communications of the IBIMA, Vol. 1.

Orodho, A. (2005). Education and Social Science Research Methods. Nairobi. Masola Publishers.

Paladino, A. 2009. Financial Champions and Masters of Innovation: Analyzing the Effects of Balancing Strategic Orientations. Journal of Product Innovation Management, 26(6), pp. 616-626.

Pearce, J.A. and Robinson, R.B. (2004) Strategic Management: Strategy, Formulation, Implementation and Control.6th Edition. Boston: McGraw-Hill 
Pfeffer, J. (1996). Seven practices of successful organizations. California Management Review, 40(2), 96124.

Rhee, J., Park, T. \& Loe D. H (2010). Drivers of innovation and performance for innovative SMEs in South Korea, International Journal of Management (30) pp 65-75.

Sanchez, R. (2014). Understanding competence-based management: Identifying and managing five modes of competence. Journal of Business Research, 57(5), 518-32.

Schoemaker, P., and Amit, R. (1994) Investment in Strategic Assets: Industry and Firm Level Perspectives, in Advances in Strategic Management (10A): Resource-Based View of the Firm). pp. 333.

Shaukat M \& Zafarullah M. (2009). Impact of Information Technology on Organizational Performance: An Analysis of Qualitative Performance Indicators of Pakistan's Banking and Manufacturing Companies. International Research Journal of Finance and Economics. 39.

Serenko, Alexander \& Bontis, Nick \& Booker, Lorne \& Sadeddin, Khaled \& Hardie, Timothy. (2010). A scientometric analysis of knowledge management and intellectual capital academic literature (1994-2008). J. Knowledge Management. 14. 3-23.

Strategic Plan - KEMRI | Wellcome Trust. (n.d.). Retrieved from http://kemri-wellcome.org/wpcontent/uploads/2016/02/Strategic-Plan-2016-2021-v6.pdf

Stonehouse, G. \& Pemberton, J. (2002). Strategic Planning in SMEs - some empirical findings. Management Decision vol.40(9), pp 853 - 861

Viseras, E. M. Baines, T., and Sweeney, M. (2005), Key success factors when implementing strategic manufacturing initiativesee. International Journal of Operations and Production Management, 25, 151-179

Wang, H. C., He, J., \& Mahoney, J. T. (2009). Firm-specific knowledge resources and competitive advantage: The roles of economic- and relationship-based employee governance mechanisms. Strategic Management Journal, 30(12), 1265-1285.

Wang, Calvin \& Walker, Elizabeth \& Redmond, Janice. (2011). Explaining the Lack of Strategic Planning in SMEs: The Importance of Owner Motivation. ECU Publications. 12.

Wernerfelt B, (2014) Employment, Markets, Contracts, and the Scope of the Firm, SSRN Electronic Journal, 10.2139/ssrn.2364411

Wiersma E W (2009) Research Methods in Education: An Introduction, 9th Edition, Stephen G. Jurs, Emeritus, The University of Toledo

Winter, S. G. (2003). Understanding dynamic capabilities. Strategic Management Journal, Vol. 24, 991995.

Wright, P. M., McMahan, G. C., \& McWilliams, A. (1994). Human resources and sustained competitive advantage: A resource-based perspective. International Journal of Human Resource Management, 5(2), 301.

W.R. Borg and M.D. Gall, (2007) Educational research: an introduction. (8th Ed.). New York: Longman

This is an open-access article published and distributed under the terms and conditions of the $(\mathrm{ccc}) \mathrm{EY}$ Creative Commons Attribution 4.0 International License of United States unless otherwise stated. Access, citation and distribution of this article is allowed with full recognition of the authors and the source.

Authors seeking to publish with an International Peer Reviewed Journal should consider https://www.ijcab.org/ by writing to the Editor at editor@ijcab.org. The articles must be quality and meet originality test. 